\title{
Organizational Commitments in Financial Service Audit With Antecedents of Organizational Justice and Job Satisfaction
}

\author{
Petrus Ridaryanto ${ }^{1}$ \\ ${ }^{1}$ Atma Jaya Indonesia Catholic University, Jakarta, Indonesia \\ Correspondence: Petrus Ridaryanto, Universitas Katolik Indonesia Atma Jaya, J1. Jend. Sudirman No.51, Karet \\ Semanggi, Setiabudi, Jakarta 12930, Indonesia
}

Received: January 17, 2020

Accepted: March 23, 2020

Online Published: June 28, 2020

doi:10.5430/ijfr.v11n4p86

URL: https://doi.org/10.5430/ijfr.v11n4p86

\begin{abstract}
Public trust in a profession is determined by the reliability, accuracy, timeliness, and quality of services or services that can be provided by the auditor profession. Although the auditor's work and performance procedures have tended to be supervised and determined strictly and formally by external institutions, studies have shown that the context of the internal environment has an effect on improving auditor performance. This study seeks to analyze the effect of organizational justice and job satisfaction in the auditor's environment on organizational commitment. It focuses more on behavioral accounting, specifically relating to the auditor's work environment, by taking the object of the treatment's influence in the organization's internal participation and involvement of auditors that is reflected by organizational commitment. By using the Structural Equation Model (SEM), the findings show that procedural justice and interactional justice are empirically proven to influence organizational commitment. On the other hand, distributive justice has no effect on organizational commitment, and job satisfaction has also been proven empirically to have no effect on organizational commitment. These results provide input for public accounting firms so as not to overlook the fairness factor in providing rewards to auditors. In the case of fairness the awarding of rewards / awards to the auditor is not only limited to the amount of reward, but also the process for determining the amount of the reward.
\end{abstract}

Keywords: organizational justice, job satisfaction, organizational commitment, audit work

\section{Introduction}

The increasing need for assurance services has led to the rapid development of the audit profession in the world. This is marked by the very rapid development of international public accounting firms. There are currently four large international accounting firms known as "Big Four" (Deloitte, Ernst \& Young, KPMG and Pricewaterhouse Coopers), with total revenues reaching 13-17 billion US dollars a year, and employees around 100.00 - 150.00 employees (Humphrey et al., 2009). Audit standards are a measure of the quality of audit work set by professional audit organizations, in Indonesia the Indonesian Institute of Certified Public Accountants (IAPI). Audit standards are the minimum requirements that must be achieved by the auditor in carrying out his audit duties. Audit standards are needed to maintain the quality of the auditor's work. Audit quality needs to be maintained so that the profession of Public Accountant still has the trust of the public. To convince readers of audit reports, the auditor must state in his report that the audit has been carried out in accordance with applicable audit standards. Auditing standard statement is considered as a provision that has legal value because everyone in this profession is obliged to comply with the established standards (Arens et al., 2011).

Community trust in a profession is determined by the reliability, accuracy, timeliness, and quality of services or services that can be provided by the profession concerned. Trust is so important because without public trust, the professional services will not be in demand. To build this trust, the behavior of professional actors needs to be regulated so that the quality of their work can be accounted for. This requires setting certain standards, so that people can be sure of the quality of the work of a professional. The Accountant's Code of Ethics requires accountants to adhere to five basic principles (IFAC, 2009) in the form of integrity, objectivity, competence, and confidentiality as well as professional behavior. Integrity is transparent and honest in all professions and business relationships. Integrity also means being fair in conveying the truth. Objectivity is not to allow biases, conflicts of interest or undue influence from other parties to influence professionalism or in policy. Professional competence is an effort to always 
improve to maintain appropriate professional knowledge and skills and to act carefully and in accordance with applicable technical provisions and professional standards. Confidentiality is an effort to respect the confidentiality of information obtained as a result of professional activities in business relationships and therefore, does not disclose or use information for the personal benefit of professionals or third parties. Finally, professional behavior refers to efforts to comply with relevant laws and regulations and avoid actions that discredit the profession.

In the work environment, work environment factors can influence auditor behavior and performance. Several studies reveal that internal auditor factors such as external locus of control, desire to move affect organizational commitment, auditor performance, auditor expertise, job satisfaction (Malone and Roberts, 1996; Fakhimuddin, 2018; Otley and Pierce, 1996b; Herrbach, 2001; Donnelly et al., 2003; Setyawan, 2004; Irawati and Mukhlasin, 2005; Maryanti, 2005; Kartika and Wjayanti, 2007; Silaban, 2009; Sijabat, 2010; Srimindarti, 2010; Febrina and Hadiprayitno, 2012). Likewise, in other studies the relationship was stated between the influence of job satisfaction on organizational commitment Pasewark and Strawser, 1996; Suwandi and Indriantoro, 1999; Parker and Kohlmeyer, 2005; Sijabat (2010) found that the higher job satisfaction perceived by auditors the higher their commitment to the organization, however, research (Curry et al., 1986; Mukhyi and Sunarti, 2007) find different results, namely there is no relationship between job satisfaction with organizational commitment. (elitian Bakhshi et al., 2009, Ponnu and Chuah, 2010; Murtaza et al., 2011; Sareshkeh et al., 2012; Ghorbanalizadeh et al., 2012; Divkan et al., 2013) concluded that there was an influence between organizational justice (distributive justice, procedural justice and interactional justice) with organizational commitment. According to Greenberg (1990), justice is a driving force that motivates one's work spirit, so the company must act fairly towards each of its employees. Assessment and recognition of employee behavior must be carried out objectively. Employees see fairness in the organization from aspects of employee benefits received (distributive justice), reward procedures (procedural justice) and interpersonal relationships between superiors and subordinates in employee appraisal procedures (interactional justice).

Organizational justice theory introduces the concept of social comparison, where employees evaluate their own input/output ratios by comparing the ratio of inputs and other employee outcomes (Carrell and Dittrich, 1978; Susilo, 2018). This theory was developed with the belief that fair treatment, or perceptions of justice motivate people to maintain fairness that is maintained in relations with their colleagues and organizations. On the other hand, procedural justice theory seeks to explain what causes workers to see procedures as fair or unjust as well as the consequences of these perceptions. The theory of procedural fairness states that workers will be motivated to work at a high level when they see the procedures used to make the distribution of results considered fair. Workers will be more motivated if they think that their performance is assessed accurately. Conversely, if workers think that their performance is not accurately assessed by their superiors, because superiors are not aware of their contribution to the organization, or maybe personal feelings for influencing performance appraisals, they will not be strongly motivated to perform at a high level. Based on this explanation procedural justice will affect organizational commitment. In this context, this study seeks to analyze the effect of organizational justice and job satisfaction in the auditor's environment on organizational commitment. Organizational justice in this study includes distributive, procedural and interactional justice.

\section{Literature Review and Hypothesis Development}

\subsection{The Effect of Distributive Justice on Organizational Commitment}

Equity theory assumes that employees try to maintain a fair ratio between the inputs they bring to the relationship and the results they receive from it (Adams, 1963). The theory of fairness in business introduces the concept of social comparison, where employees evaluate their own input / output ratios by comparing the ratio of inputs and other employee outcomes (Carrell and Dittrich, 1978). Rewards that are not allocated equally will form employee de-motivation (Folger and Cropanzano, 1998). Cohen-Charash and Spector (2001) describe results in the form of rewards received by individuals for input and rewards perhaps in the form of salary or inner satisfaction, or a sense of achievement. Perception of injustice will cause a decrease in organizational commitment to employees (Lam et al., 2002). Thus, the factor of distributive justice is one of the factors that influence the organizational commitment of employees within their organization.

The results of research conducted on the effect of distributive justice on organizational commitment by previous researchers shows that distributive justice has a positive effect on organizational commitment. The results of this study include, the results of research Bakhshi et al. (2009) who conducted a survey of 128 employees working at Medical College using regression analysis, found that distributive justice is significantly related to organizational commitment. The results of research by Ismail et al. (2009) who conducted a survey of 189 academic employees working in tertiary institutions in Malaysia, using regression analysis found that distributive justice was significantly 
related to organizational commitment. The results of research by Ponnu and Chuah (2010) who conducted a survey of 172 employees of various organizations in Malaysia, using regression analysis, found that distributive justice was significantly related to organizational commitment. Murtaza et al. (2011) research conducted a survey of 140 employees working at the Water and Power Authority (WAPDA) in Pakistan using t-test analysis, found that distributive justice and procedural fairness were significantly related to organizational commitment, but fairness procedural has the most powerful influence. The results of Siavas Sareshkeh et al. (2012) research on sports federation workers in Iran, using multiple regression analysis, found that distributive justice directly affects organizational commitment. Based on the results of previous studies that show that there is a relationship between distributive justice to organizational commitment, then this study predicts the higher the distributive justice perceived by the auditor, the higher the organizational commitment. Conversely, the lower the perception of distributive justice by auditors, the lower the commitment to the organization. Thus this study proposes the following hypothesis formulation.

\section{H1: Distributive justice has a positive effect on organizational commitment}

\subsection{Procedural Justice Towards Organizational Commitment}

From the results of previous studies that have been conducted on the effect of procedural justice on organizational commitment, most find that procedural justice is positively related to organizational commitment. The results of this study include, the results of the research of Bakhshi et al. (2009) who conducted a survey of 128 employees working at Medical College using regression analysis, found that procedural fairness is related significantly to organizational commitment. The results of research by Ponnu and Chuah (2010) who conducted a survey of 172 employees of various organizations in Malaysia, using regression analysis, found that procedural fairness was significantly related to organizational commitment. Murtaza et al. (2011) research conducted a survey of 140 employees working in the Water and Power Authority (WAPDA) in Pakistan using t-test analysis, found that distributive justice and procedural justice significantly related to organizational commitment, but fairness procedural has the strongest influence. The results of Sareshkeh et al. (2012) research on sports federation workers in Iran, using multiple regression analysis, found that procedural justice directly affected organizational commitment. Based on the results of previous studies, most support the relationship between procedural justice and organizational commitment. Therefore this study still predicts the higher procedural fairness perceived by the auditor, the higher the organizational commitment. Conversely the lower the perception of auditor procedural justice, the lower the commitment to the organization. Thus this study proposes the following hypothesis formulation.

$\mathrm{H} 2$ : Procedural justice has a positive effect on organizational commitment.

\subsection{Effect of Interactional Justice on Organizational Commitment}

Interactional justice is a subcomponent of organizational justice, which focuses on two types of interpersonal relationships (Greenberg, 1987a, 1987b). The first is interpersonal justice relations, reflecting the extent to which people are treated with courtesy, dignity, and respect by the authorities or third parties involved in carrying out procedures or determining outcomes. Second, information justice focuses on explanations given to people who convey information about why procedures are used in a certain way or why results are shared in a particular way. Perception of fairness or injustice in the organization will affect the commitment to the organization.

The results of previous studies that examined the effect of interactional justice on organizational commitment for the most part found that interactional justice is positively related to organizational commitment.

The results of this study include, the results of research by Kadaruddin and Mardiana (2012) who conducted a survey of 83 employees of the Tax Office in Makassar using regression analysis found that interactional justice has a significant influence on organizational commitment. The results of Sareshkeh et al. (2012) who conducted a survey of sports federation workers in Iran using data analysis: Multiple Regression, found that interactional justice directly affects organizational commitment. The results of research by Nili and Shekarchizadeh (2012), which conducted a survey of 300 employees in Isfahan Municipality using $t$ test data analysis and multiple regression, found that interactional justice has an influence on organizational commitment. The research results of Divkan et al. (2013) who conducted a survey of 100 employees of health education organizations using test analysis $t$ and multiple regression, found that interactional justice has an influence on organizational commitment. Based on the results of previous studies above conclusions support the relationship between interactional justice and organizational commitment. Therefore this study predicts the higher the interactional fairness perceived by the auditor, the higher the organizational commitment. Conversely the lower the auditor's perception of interactional justice, the lower the commitment to the organization.

H3: Interactional justice has a positive effect on organizational commitment 


\subsection{Job Satisfaction of Organizational Commitment}

The theory of justice states people will be satisfied as long as they feel there is justice (Adams, 1963). Equity and inequity are obtained by comparing oneself with others. Someone will be satisfied with his work if the ratio of input-outcomes from himself is relatively the same as the ratio of input-outcomes of others, on the contrary will be dissatisfied with his work if the ratio of input-outcomes from himself is not the same as the ratio of input-outcomes of others. work varies according to the value system that applies to him. Job satisfaction is one of the factors that can influence a person's behavior in his workplace (Aranya et al., 1982).

The results of this study include, the results of research Ameen et al. (1995) who conducted a survey of 72 academic accountants in tertiary institutions in the USA, found that job satisfaction is positively related to organizational commitment. The results of the Pasewark and Strawser research (1996) a survey of 64 staff level auditors in the four Big Six public accounting firms, found that job satisfaction was positively related to organizational commitment. The results of the study by Suwandi and Indriantoro (1999) who conducted a survey of 174 auditors at public accounting firm in Indonesia, found that job satisfaction was positively related to organizational commitment. Panggabean research results (2004) which conducted a survey of employees working in several companies, found that job satisfaction is positively related to organizational commitment. The results of the study of Parker and Kohlmeyer (2005) who conducted a survey of 76 auditors of all levels in five major public accounting firms in Canada, found that job satisfaction is positively related to organizational commitment. The results of Kalbers and Cenker's research (2007) who conducted a survey of 334 auditors at all international and national accounting firms in the USA, found that job satisfaction was positively related to organizational commitment. The results of Hasmarini and Yuniawan's research (2008) which conducted a survey of 86 employees of one foreign private company in Indonesia, found that job satisfaction was significantly related to affective organizational commitment. Based on the results of the research above, the conclusions support the influence between job satisfaction on organizational commitment. So this study predicts the higher job satisfaction, the higher the organizational commitment. Conversely the lower the job satisfaction, the lower the organizational commitment.

H4: Job satisfaction has a positive effect on organizational commitment

\section{Method}

This study seeks to examine and explain the effect of predictors of organizational justice (distributive justice, procedural justice and interactional justice) and job satisfaction on organizational commitment. The population in this study is the auditor who works at the public accounting firms in Jakarta. Related to determining the number of samples, according to Ghozali (2008), the size of the sample size has an important role in the interpretation of SEM results. The sample size provides the basis for estimating sampling error, using the minimum Maximum Likelihood (ML) estimation model required for sample 100, the ML method increases its sensitivity to detect differences between data. However, once the sample becomes large (above 400 to 500), the ML method becomes very sensitive and always produces a significant difference so that the Goodness of Fit measurement becomes poor. So it is recommended that a sample size between 100 to 200 should be used for the ML estimation method. The number of samples planned by researchers in this study were as many as 200-400 respondents. Research data were collected through questionnaires.

To measure the construct of distributive justice, an instrument used by Tang and Sarsfield-Baldwin (1996) with a Cronbach alpha coefficient of 0.95 was used. This instrument includes 5 questions with a 7 -point Likert scale ranging from 1 (very unfair) to 7 (very fair). In this study, procedural fairness is interpreted as the auditor's tendency to make evaluations of supervisors in accordance with procedures or methods that apply in making decisions in the context of work. Measurements were made using a 7-point Likert scale. Furthermore, to measure the construct of interactional justice the instrument that Tang and Sarsfield-Baldwin (1996) used was used with a cronbach alpha coefficient of 0.95 . This instrument includes 16 questions with a seven-point Likert scale ranging from 1 to 7 . A high score indicates that respondents have a high perception of fairness towards their organization.

In this study, job satisfaction is operationally defined by measuring the level of respondents' agreement on a number of questions about job satisfaction using the construct of job satisfaction an instrument of index of job satisfaction that has been used by Kalbers and Cenker (2007). Cronbach alpha coefficient value is 0.92 . This instrument includes 7 questions with a 7-point Likert scale ranging from 1 (strongly disagree) to 7 (strongly agree). Organizational commitment is defined as the level of attachment and recognition of individuals to the organization (Steers, 1977). To measure the construct of organizational commitment the organizational commitment scale (OCS) instrument from Meyer et al. (1993) used a Cronbach alpha coefficient value of 0.92. This instrument includes 24 questions with a 7-point Likert scale ranging from 1 (strongly disagree) to 7 (strongly agree). 
The analysis was conducted by using Structural Equation Model /SEM. The program used to analyze data was the Analysis Model of Structure (AMOS 21.0) program.

\section{Results}

Based on the profile of respondents based on the characteristics of the position structure, there are 43 male auditors who hold junior auditor positions, 108 senior auditors and 36 others as managers. Meanwhile, there are 27 women who hold junior auditors, 43 seniors and 5 as managers. From the education level, the majority who hold senior auditor positions are auditors with undergraduate education with a total of 133 people. On the other hand, only 18 auditors with master graduates occupying senior managers. From the working period, most junior auditors have worked for less than 2 years with 65 people, and senior auditors with a 2-4 year tenure of 124 people. Demographic findings also indicate that the majority of respondents have not yet obtained a register as an accountant.

Table 1. Profile of respondents based on job structure characteristics

\begin{tabular}{llll}
\hline Characteristics & Junior & Senior & Manager \\
\hline Gender: & & & \\
\hline Male & 43 & 108 & 36 \\
\hline Female & 27 & 43 & 5 \\
\hline Education: & & & \\
\hline Bachelor & 70 & 133 & 34 \\
\hline Master & - & 18 & 7 \\
\hline Years of service: & & & \\
\hline$<2$ years & 65 & - & - \\
\hline $2-4$ years & 5 & 124 & - \\
\hline 4 - 6 years & - & 21 & 11 \\
\hline$>6$ years & - & 6 & 30 \\
\hline Status register: & 10 & 38 & 15 \\
\hline Registered Accountant & 60 & 104 & 26 \\
\hline No Registered Accountant & & & \\
\hline
\end{tabular}

The second analysis is the index number that highlights the number of respondents' answers to various questions. Table 2 regarding distributive justice shows an mean index number of 57.7 which is interpreted as being moderate. This means that respondents feel that giving rewards in the public accounting firm is fair enough. The dominant indicator in the perception of distributive justice is the suitability of rewards compared to education and experience with an index value of 62.2. On the other hand, the mean index of organizational commitment in table 4.8 shows that the mean index of 65.9 is interpreted as moderate. However, the auditor's willingness to remain an employee throughout his career in public accounting firm shows a low index compared to the mean index value of 53.1. This means that even though auditors have been given fairly fair rewards, they do not have the commitment to serve in the public accounting firm for a long period of time.

Table 2. Distributive justice variable index values

\begin{tabular}{lllllllll}
\hline \multicolumn{7}{c}{ Percentage of Respondents' Answers } \\
\hline Indicator & 1 & 2 & 3 & 4 & 5 & 6 & 7 & index \\
\hline X1 & 11.1 & 12.2 & 14.5 & 26.3 & 15.6 & 15.6 & 4.6 & 57.0 \\
\hline X2 & 6.1 & 14.1 & 22.9 & 19.1 & 20.2 & 9.2 & 8.4 & 56.3 \\
\hline X3 & 15.3 & 14.9 & 15.3 & 14.9 & 14.5 & 16.8 & 8.4 & 54.7 \\
\hline X4 & 7.6 & 8.0 & 19.1 & 17.6 & 15.6 & 17.9 & 14.1 & 62.2 \\
\hline X5 & 10.3 & 13.7 & 15.3 & 17.6 & 17.9 & 14.9 & 10.3 & 57.9 \\
\hline Mean & & & & & & & 57.6 \\
\hline
\end{tabular}


Descriptive empirical data on procedural fairness shows an mean index value of 49.5 which is interpreted as moderate. This indicates that the mean respondent felt that the perception of procedural fairness in public accounting firm was fair enough. The dominant indicator of the perception of procedural fairness is more due to the factor of fairness on the performance appraisal carried out by the supervisor or supervisor. Likewise, in table 4.7 descriptive data of organizational commitment the mean index value of 65.9 is interpreted as being moderate. This means that the perception of procedural fairness that is fair enough causes the public auditors to be committed enough to survive in a longer working period.

Furthermore, the analysis of index numbers on interactional justice shows an mean index value of 58.8 which is interpreted as moderate. This indicates that the mean respondent felt that the perception of interactional justice in public accounting firm was fair enough. Table 3 regarding job satisfaction which shows an mean index figure of 57.7 which is interpreted as being moderate.

Table 3. Variable index of job satisfaction index

\begin{tabular}{lccllllll}
\hline \multicolumn{7}{c}{ Percentage of Respondents' Answers } \\
\hline Indicator & 1 & 2 & 3 & 4 & 5 & 6 & 7 & index \\
\hline X28 & 12.6 & 9.5 & 13.7 & 16,4 & 15.6 & 14.5 & 17.6 & 54,9 \\
\hline X29 & 8.0 & 13.7 & 16.8 & 12,2 & 19,1 & 16.4 & 13.7 & 56.6 \\
\hline X30 & 9.5 & 13.0 & 14.9 & 18.7 & 15.6 & 17.9 & 10.3 & 58.9 \\
\hline X31 & 9.5 & 9.5 & 14.5 & 21.0 & 20.6 & 13.7 & 11,1 & 59.8 \\
\hline X32 & 13.4 & 15.6 & 17.2 & 16.4 & 16.8 & 10.7 & 9.9 & 54.2 \\
\hline X33 & 9.5 & 13.4 & 22.9 & 18.3 & 16.8 & 13.0 & 6.1 & 54.7 \\
\hline X34 & 9.5 & 16.0 & 21.0 & 17.6 & 16.0 & 13.0 & 6.9 & 62.5 \\
\hline Mean & & & & & & & & 57.7 \\
\hline
\end{tabular}

Analysis of organizational commitment shows an mean index of 65.9 which is also interpreted to be moderate. However, the dominant indicator on job satisfaction related to the auditor's enjoyment in working at public accounting firm shows a fairly high index number that is 62.5 not in line with the auditor's desire to last longer at public accounting firms, this is indicated by a lower indicator that is equal to an index value of 53.1. This means that although the auditor is quite satisfied with working in the Public Accounting Firm, it does not cause them to want to continue working throughout their career, because the auditor's job satisfaction is due to pleasant audit activities with varying audit objects while to remain working throughout his career is highly determined expectations of the sustainability of the organization in the long run long. Likewise, an analysis of index numbers on organizational commitment obtained an mean index value of 65.9 , which is interpreted as being moderate, meaning that the auditor is still quite committed to staying afloat as labor in the firm. This means that with the perception of fair interactional justice, it will encourage auditors in public accounting firm Jakarta to be more committed to staying longer in their organizations.

Furthermore, the confirmatory test analysis in Table 4 shows the results of the confirmatory factor test finding factor loading $(\lambda)$ values greater than 0.5 on all latent variables, this proves that the items can explain the uni-dimensionality of latent variables. The strength of the dimensions in forming latent variables can be proven by looking at the probability $<0.05$ meaning that the items are significant as the dimensions of the latent variables formed. 
Table 4. Confirmatory test results

\begin{tabular}{|c|c|c|c|c|c|c|c|}
\hline Variable & Item & $\lambda$ & $\mathrm{P}$ & Variable (cont.) & Item & $\lambda$ & $\mathrm{P}$ \\
\hline \multirow[t]{5}{*}{ Dist. Just (DJ) } & DJ1 & .711 & 0.00 & \multirow[t]{5}{*}{ Inter. Just (IJ) } & IJ19 & .614 & 0.00 \\
\hline & DJ 2 & .812 & 0.00 & & IJ22 & .772 & 0.00 \\
\hline & DJ 3 & .689 & 0.00 & & IJ23 & .815 & 0.00 \\
\hline & DJ 4 & .675 & 0.00 & & IJ24 & .787 & 0.00 \\
\hline & DJ 5 & .669 & 0.00 & & IJ25 & .708 & 0.00 \\
\hline \multirow[t]{6}{*}{ Proc. Just (PJ) } & PJ6 & .656 & 0.00 & \multirow[t]{7}{*}{ Job Sat. (JS) } & JS28 & .617 & 0.00 \\
\hline & PJ 7 & .620 & 0.00 & & JS29 & .637 & 0.00 \\
\hline & PJ 8 & .779 & 0.00 & & JS30 & .613 & 0.00 \\
\hline & PJ 9 & .809 & 0.00 & & JS31 & .601 & 0.00 \\
\hline & PJ10 & .752 & 0.00 & & JS32 & .625 & 0.00 \\
\hline & PJ11 & .667 & 0.00 & & JS33 & .605 & 0.00 \\
\hline \multirow[t]{5}{*}{ Inter. Just (IJ) } & IJ12 & .609 & 0.00 & & JS34 & .601 & 0.00 \\
\hline & IJ13 & .604 & 0.00 & \multirow[t]{4}{*}{ Org. Com. (OC) } & OC35 & .810 & 0.00 \\
\hline & IJ16 & .602 & 0.00 & & OC36 & .807 & 0.00 \\
\hline & IJ17 & .618 & 0.00 & & OC37 & .787 & 0.00 \\
\hline & IJ18 & .511 & 0.00 & & OC38 & .724 & 0.00 \\
\hline
\end{tabular}

The first hypothesis states that distributive justice has a positive effect on organizational commitment. The results of data processing showed a CR value of 0.080 with a probability of 0.936 . Because the $C R$ value generated from the calculation is smaller than the critical value at the 0.05 (5\%) significance level of 1.998 and the resulting probability value (0.936) is $>0.05$, it can be concluded that the distributive justice variable is statistically proven not to have a positive effect on organizational commitment. Thus, the first hypothesis is rejected.

This empirically means that distributive justice does not affect organizational commitment. This finding shows that perceptions of distributive justice cannot increase organizational commitment. Distributive justice is related to one's perception of how rewards are distributed among employees (Greenberg, 2003), while organizational commitment is related to one's desire to remain a member of a particular organization (Levy, 1998). Statistical test results show there is no effect of distributive justice on organizational commitment.

The second hypothesis states that procedural justice has a positive effect on organizational commitment. The results of data processing showed a CR value of 4,056 with a probability of 0.00 . Because the CR value generated from the calculation is greater than the critical value at the $0.05(5 \%)$ significance level of 1.998 and the resulting probability value $(0.00)$ is $<0.05$, it can be concluded that the procedural justice variable is statistically proven to have a significant positive effect on organizational commitment. Thus the second hypothesis is accepted. This finding indicates a high perception of procedural fairness that will increase the auditor's organizational commitment.

This shows that procedural justice affects organizational commitment. This means that perceptions of procedural fairness can encourage increased organizational commitment. Perceptions of procedural fairness relate to employees' perceptions of the procedures used in making decisions in granting rewards. While organizational commitment is related to the desire of employees to remain part of the organization. Statistical test results show that procedural justice has a positive effect on organizational commitment.

Table 5. Hypothesis testing

\begin{tabular}{lllllc}
\hline \multicolumn{1}{c}{ Hypothesis } & Std Est. & Estimate & S.E. & C.R. & P \\
\hline OC <--- DJ & .007 & .009 & .118 & 1.080 & 936 \\
\hline OC <--- PJ & .293 & .385 & .095 & 4.056 & $* * *$ \\
\hline OC <--- IJ & .258 & .350 & .093 & 3.764 & $* * *$ \\
\hline OC <--- JS & -.155 & -.201 & .121 & -1.659 & .097 \\
\hline $\begin{array}{l}\text { OC: Organizational } \\
\text { procedural justice; JS: job satisfaction }\end{array}$ & & & & \\
\hline
\end{tabular}

The third hypothesis states that interactional justice has a positive effect on organizational commitment. The results of data processing showed a CR value of 3.764 with a probability of 0.00 . Because the CR value generated from the calculation is greater than the critical value at the 0.05 significance level of 1.998 and the resulting probability value 
of $0.00<0.05$, it can be concluded that the interactional justice variable is statistically proven to have a significant positive effect on organizational commitment. Thus the third hypothesis is accepted. These findings indicate a high perception of interactional justice that will make the auditor organization's commitment to be higher.

Empirically, the results of testing this hypothesis state that interactional justice influences organizational commitment. This means that increasingly higher perceptions of interactional justice can encourage increased organizational commitment. Interactional justice is justice that involves the leadership interpersonal relationship with employees which includes trust, respect and neutrality (Tyler, 1991). Whereas organizational commitment is a strong desire of the workforce to remain a particular organization (Levy, 1998). The results of statistical tests show the positive influence of perceptions of interactional justice on organizational commitment. This means that interpersonal relations between public accounting office leaders and auditors who consider politeness, dignity, respect and objectivity in performance appraisal procedures will encourage increasing the auditor's commitment to continue working at the public accounting offices.

The fourth hypothesis states that job satisfaction has a positive effect on organizational commitment. The results of data processing showed a CR value of $-1,659$ with a probability of 0.097 . Because the CR value generated from the calculation is greater than the critical value at the 0.05 significance level of 1.998 and the resulting probability value of $0.097>0.05$, it can be concluded that the variable job satisfaction is not statistically proven to have a significant positive effect on commitment organizational Thus, the fourth hypothesis is rejected. The results of testing this hypothesis states that job satisfaction has no effect on organizational commitment. This means job satisfaction cannot encourage increasing organizational commitment. Job satisfaction is a degree of likes or dislikes of the workforce towards various aspects of their work (Locked, 1969), and organizational commitment is a strong desire of the workforce to remain a workforce in a particular organization (Levy, 1998). The results of statistical tests show that job satisfaction cannot encourage increased organizational commitment.

\section{Conclusion}

The results revealed that distributive justice had no effect on organizational commitment. This finding indicates that the perception of distributive justice by auditors did not really encourage organizational commitment in the Jakarta Public Accounting Firm. On the other hand, procedural justice has been shown to empirically influence organizational commitment. This finding indicates that the perception of procedural fairness by auditors can encourage increased organizational commitment in public accounting firms in Jakarta. Equally, interactional justice has a positive effect on organizational commitment. These findings indicate that perceptions of procedural fairness in public accounting firms in Jakarta can encourage increased organizational commitment in auditors. The final finding, job satisfaction is empirically proven has no effect on organizational commitment. This finding indicates that job satisfaction felt by auditors in public accounting firms in Jakarta cannot encourage increasing auditor organizational commitment.

The evidence of this empirical research shows that organizational justice in the form of procedural and interactional justice influences the auditor's organizational commitment. The results of this study provide input for public accounting firms so as not to overlook the fairness factor in providing rewards to auditors. In the case of fairness the awarding of rewards / awards to the auditor is not only limited to the amount of reward, but also the process for determining the amount of the reward.

The limitation of this study is that it is limited to examining the influence of organizational justice and job satisfaction on organizational commitment. On the other hand, there are many other factors that can influence auditor organizational commitment. Future research can expand research on factors that influence organizational commitment in the context of auditor work, by broadening sample distribution and analyzing auditor organizational commitment variables.

\section{References}

Adams, J. S. (1963). Towards an understanding of inequity. The Journal of Abnormal and Social Psychology, 67(5), 422. https://doi.org/10.1037/h0040968

Ameen, E. C., Jackson, C., Pasewark, W. R., \& Strawser, J. R. (1995). An empirical Investigation of the antecedents and consequences of job insecurity on the Academic accountants. Issues in Accounting Education, 10(1).

Aranya, N., Lachman, R., \& Amernic, J. (1982). Accountants' job satisfaction: A path analysis. Accounting, Organizations and Society, 7(3), 201-215. https://doi.org/10.1016/0361-3682(82)90001-0

Arens, A. A., Elder, R. J., Beasley, M. S., \& Jusuf, A. A. (2011). Jasa Audit dan Assurance. Penerbit Erlangga-Jakarta.

Bakhshi, A., Kumar, K., \& Rani, E. (2009). Organizational Justice Perceptions as Predictor of Job Satisfaction and Organization Commitment. International journal of Business and Management, 4(9), 145. https://doi.org/10.5539/ijbm.v4n9p145 
Carrell, M. R., \& Dittrich, J. E. (1978). Equity theory: The recent literature, methodological considerations, and new directions. Academy of Management Review, 3(2), 202-210. https://doi.org/10.5465/amr.1978.4294844

Cohen-Charash, Y., \& Spector, P. E. (2001). The role of justice in organizations: A meta-analysis. Organizational Behavior and Human Decision Processes, 86(2), 278-321. https://doi.org/10.1006/obhd.2001.2958

Curry, J. P., Wakefield, D. S., Price, J. L., \& Mueller, C. W. (1986). On the causal ordering of job satisfaction and organizational commitment. Academy of Management Journal, 29(4), 847-858. https://doi.org/10.2307/255951

Divkan, B., Sartipi, V., Zanganeh, I., \& Rostami, R. (2013). Relationship Between Organizational Justice With Job Satisfaction And Organizational Commitment in Physical Education Organizations Of Tehran Islamic Azad university East Tehran branch. Advances in Environmental Biology, 7(6), 1162-1167.

Donnelly, D. P., Quirin, J. J., \& O'Bryan, D. (2003). Auditor acceptance of dysfunctional audit behavior: An explanatory model using auditors' personal characteristics. Behavioral Research in Accounting, 15(1), 87-110. https://doi.org/10.2308/bria.2003.15.1.87

Fakhimuddin, M. (2018). Reconsidering Accounting Information Systems: Effective Formulations for Company's Internal Control. Arthatama Journal of Business Management and Accounting, 2(2).

Febrina, H. L., \& Hadiprayitno, P. B. (2012). Analisis Pengaruh Karakteristik Personal Auditor Terhadap Penerimaan Auditor Atas Dysfunctional Audit Behavior (Studi Empiris pada Kantor Akuntan Publik di Jawa Tengah dan Di Yogyakarta). Dissertation, Universitas Diponegoro.

Folger, R., \& Cropanzano, R. (1998). Organizational justice and human resources management. Thousand Oaks, C.A: Sage.

Ghorbanalizadeh, F., Safania, A. M., \& Tayebi, S. M. (2012). Impact of Organizational Justice Perceptions on Job Satisfaction and Organizational Commitment: the Iran's Ministry of Sport Perspective.

Ghozali, I. (2008). Structural Equation Modelling: Model Alternatif dengan Partial Least Square. Universitas Diponegoro, Semarang.

Greenberg, J. (1987). A taxonomy of organizational justice theories. Academy of Management Review, 12(1), 9-22. https://doi.org/10.5465/amr.1987.4306437

Greenberg, J. (1987). Reactions to procedural injustice in payment distributions: Do the means justify the ends? Journal of Applied Psychology, 72(1), 55. https://doi.org/10.1037/0021-9010.72.1.55

Greenberg, J. (1990). Organizational justice: Yesterday, today, and tomorrow. Journal of Management, 16(2), 399-432. https://doi.org/10.1177/014920639001600208

Greenberg, J., \& Baron, R. (2003). Behavior in Organizations. Prentice Hall, New Delhi.

Hasmarini, D. P., \& Yuniawan, A. (2008). Pengaruh Keadilan Prosedural Dan Distributif Terhadap Kepuasan Kerja Dan Komitmen Afektif. Jurnal Bisnis Strategi, 17(1), 99-118.

Herrbach, O. (2001). Audit quality, auditor behaviour and the psychological contract. European Accounting Review, 10(4), 787-802. https://doi.org/10.1080/09638180127400

Humphrey, C., Loft, A., \& Woods, M. (2009). The global audit profession and the international financial architecture: Understanding regulatory relationships at a time of financial crisis. Accounting, Organizations and Society, 34(6), 810-825. https://doi.org/10.1016/j.aos.2009.06.003

IFAC. (2009). Code of Ethic for Professional Accountants. IFAC.

Irawati, Y., \& Mukhlasin, T. (2005). Hubungan Karakteristik Personal Auditor Terhadap Tingkat Penerimaan Penyimpangan Perilaku Dalam Audit. Prosiding Simposium Nasional Akuntansi, 929-940.

Ismail, A., Ong, G., Tan, C., Ibrahim, Z., Ajis, M. N. E., \& Dollah, N. F. (2009). The indirect effect of distributive justice in the relationship between pay structure and work attitudes and behavior. European Journal of Social Sciences, 11(2), 234-248.

Kadaruddin, A. R., \& Mardiana, R. (2012). Pengaruh keadilan Distributive, keadilan procedural dan keadilan interaksional terhadap Kepuasan kerja pegawai pajak di kota Makasar. Manajemen \& Keuangan.

Kalbers, L. P., \& Cenker, W. J. (2007). Organizational commitment and auditors in public accounting. Managerial Auditing Journal, 22(4), 354-375. https://doi.org/10.1108/02686900710741928

Kartika, I., \& Wjayanti, P. (2007). Locus of Control Sebagai Antesenden Hubungan Kinerja pegawai dan Penerima Prilaku disfungsional Audit. Simposium Nasional Akuntansi, X, 21-28.

Lam, S. S., Schaubroeck, J., \& Aryee, S. (2002). Relationship between organizational justice and employee work outcomes: a cross-national study. Journal of Organizational Behavior, 23(1), 1-18. https://doi.org/10.1002/job.131 
Levy, P. E., \& Williams, J. R. (1998). The role of perceived system knowledge in predicting appraisal reactions, job satisfaction, and organizational commitment. Journal of Organizational Behavior, 19(1), 53-65. https://doi.org/10.1002/(SICI)1099-1379(199801)19:1<53::AID-JOB826>3.0.CO;2-D

Locked, E. A. (1969). What job satisfaction. Organizational Behavioral and Human Performance, 4, 309-336. https://doi.org/10.1016/0030-5073(69)90013-0

Malone, C. F., \& Roberts, R. W. (1996). Factors associated with the incidence of reduced audit quality behaviors. Auditing: A Journal of Practice \& Theory, 15(2).

Maryanti, P. (2005). Analisis penerimaan auditor atas dysfunctional audit behavior: pendekatan karakteristik personal auditor (Studi empiris pada kantor akuntan publik di Jawa). Dissertation, Universitas Diponegoro.

Meyer, J. P., Allen, N. J., \& Smith, C. A. (1993). Commitment to organizations and occupations: Extension and test of a three-component conceptualization. Journal of Applied Psychology, 78(4), 538. https://doi.org/10.1037/0021-9010.78.4.538

Mukhyi, M. A., \& Sunarti, T. (2007). Hubungan antara kepuasan kerja dengan komitmen organisasi dalam lingkungan institusi pendidikan di Kota Depok. Paper read at Proceeding PESAT.

Murtaza, G., Shad, I., Shahzad, K., Kamal Shah, M., \& Ahmed Khan, N. (2011). Impact of distributive and procedural justice on Employees commitment : A case of public sector organization of Pakistan. European Journal of Economics, Finance and Administrative Science, (29).

Nili, M., Hendiyani, M., \& Shekarchizadeh. (2012). Measuring the impact of perceive justice on organization commitment in Isfahan Municipality. Interdiscipline Journal of Contreporary Research in Business, 4(5).

Otley, D. T., \& B. J. Pierce. (1996). The operation of control systems in large audit firms. Auditing, 15, 65-84.

Panggabean, M. S. (2004). Komitmen organisasi sebagai mediator variable bagi Pengaruh kepuasan kerja terhadap keinginan untuk pindah. Jurnal Bisnis Dan Akuntansi, 6(1), 90-113.

Parker, R. J., \& Kohlmeyer, J. M. (2005). Organizational justice and turnover in public accounting firms: A research note. Accounting, Organizations and Society, 30(4), 357-369. https://doi.org/10.1016/j.aos.2004.05.001

Pasewark, W. R., \& Strawser, J. R. (1996). The determinants and outcomes associated with job insecurity in a professional accounting environment. Behavioral Research in Accounting, 8, 91-113.

Ponnu, C., \& Chuah, C. (2010). Organizational commitment, organizational justice and employee turnover in Malaysia. African Journal of Business Management, 4(13), 2676-2692.

Sareshkeh, S. K., Ghaziani, F. G., \& Tayebi, S. M. (2012). Impact of organizational justice perception on job satisfaction and organizational commitment: The iranian sports federation perspective. Annals of Biological Research, 3(8), 4229-4238.

Setyawan, D. (2004). Analisis Pengaruh Kepemimpinan Q (IQ, EQ, SQ) Terhadap Komitmen Organisasional Karyawan. Unpublished undergraduate thesis, Universitas Katolik Soegijapranata, Semarang.

Sijabat, J. (2010). Karateristik personal auditor dan penerimaan perilaku menyimPang dalam pelaksanaan audit. Dissertation, Universitas Diponegoro.

Silaban, A. (2009). Perilaku Disfungsional Auditor dalam Pelaksanaan Program Audit. Dissertation, Universitas Diponegoro.

Srimindarti, C. (2010). Penerimaan Perilaku Audit Disfungsional Berdasarkan Pada Faktor Internal Individu Auditor. Dissertation, Universitas Diponegoro.

Steers, R. M. (1977). Antecedents and outcomes of organizational commitment. Administrative Science Quarterly, 46-56. https://doi.org/10.2307/2391745

Susilo, D. E. (2018). The Effects of Corporate Social Responsibility on Corporate Value. Arthatama Journal of Business Management and Accounting, 2(2), 14-26.

Suwandi, \& Indriantoro, N. (1999). Model turnover Pasewark dan Strawser: Studi empiris pada lingkungan Akuntan Publik. Jurnal Riset Akuntansi Indonesia, 2(2), 173-195.

Tang, T. L.-P., \& Sarsfield-Baldwin, L. J. (1996). Distributive and Procedural Justice as Related to Satisfaction and Commitment.

Tyler, T. R. (1991). Using procedures to justify outcomes: Testing the viability of a procedural justice strategy for managing conflict and allocating resources in work organizations. Basic and Applied Social Psychology, 12(3), 259-279. https://doi.org/10.1207/s15324834basp1203_2 